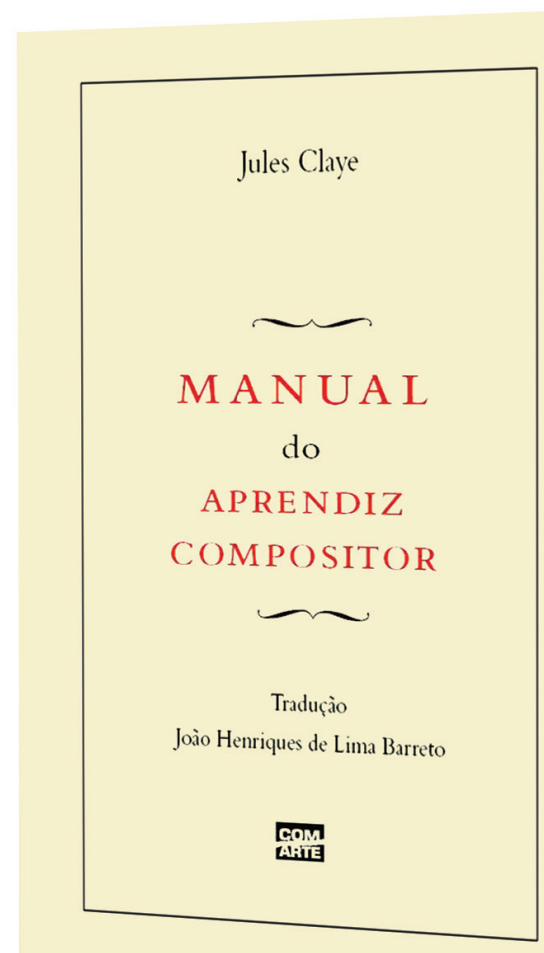

\title{
Compondo um outro tempo: práticas e saberes de tipógrafos oitocentistas
}

\section{Tania Regina de Luca}

Manual do aprendiz compositor, de Jules Claye,

trad. João Henriques de Lima Barreto, São Paulo, Com-Arte, 2019, 176 p. 

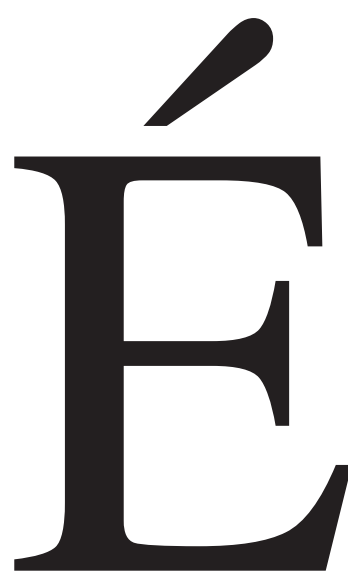

possível que uma das marcas a ser evocada como típica da nossa época seja a impaciência. Alguns segundos a mais para ligar um computador, obter resposta de um sítio de busca ou fazer uma operação bancária são suficientes provocar reações coléricas. Acostumados com o imediato e com a rápida obsolescência dos objetos que nos cercam, a voracidade do e pelo novo acaba por ser naturalizada. Nesse contexto, nada mais oportuno do que o relançamento da edição do Manual do aprendiz compositor, originalmente escrito pelo francês Jules Claye, traduzido e adaptado para o português por João Henriques de Lima Barreto e publicado em 1888 pela Imprensa Nacional.

A atual edição, sob responsabilidade da Com-Arte, editora-laboratório do Curso de Editoração da Escola de Comunicações e Artes (ECA) da USP, é acompanhada por paratextos que esclarecem a trajetória pessoal e profissional do tipógrafo João Henriques, pai do famoso escritor Afonso Henriques de Lima Barreto, além de levar a cabo cuidadosa comparação com o trabalho original de Jules Alexandre Saturnin Claye (18061886), ele também tipógrafo, fundidor de tipos, impressor, livreiro e autor, além do Manuel de l'apprenti compositeur, de volume de poesias ${ }^{1}$. A empreitada evidencia que não se tratou de mera versão do texto escrito pelo colega parisiense, mas de um trabalho de adaptação, em conformidade com a realidade e as necessidades locais.

Ao longo de 25 capítulos, o leitor é introduzido à arte da composição que, é bom

1 Para detalhes sobre a importância de Jules Claye no cenário parisiense, ver: Ruth-Ellen St. Onge, Printed in perfect harmony: publishers of poetry in France (1851-1900), thesis philosophy, Toronto, Département d'Études Françaises/University of Toronto, 2014.

TANIA REGINA DE LUCA é professora de História do Brasil Republicano pela Universidade Estadual Paulista (Unesp) e pesquisadora do CNPq. 
frisar, seguia procedimentos que remontavam à época de Gutenberg. O processo de mecanização, que substitui a paciente seleção de cada tipo para formar palavras, linhas e páginas, deu-se com a invenção da linotipo (1885), máquina que somente se difundiu entre nós no início do século XX. Em consonância com o objetivo do Manual, ou seja, o de formar o futuro compositor, cada passo do processo foi cuidadosamente explicado, a começar pelos instrumentos de trabalho, o componedor, a caixa na qual os tipos móveis eram distribuídos e cuja posição de maiúsculas e minúsculas está na origem dos termos caixa alta e caixa baixa, que seguimos utilizando, passando por todos os detalhes que implicavam a fatura manual do texto e que exigiam não apenas habilidades técnicas específicas, mas também sensibilidade estética, tendo em vista apresentar um produto bem-acabado. Não por acaso, os tipógrafos, que se autodenominavam "filhos de Gutenberg" e continuadores da obra do mestre, insistiam no caráter artístico do seu ofício e na função social que cumpriam. Em muitas passagens do Manual, evoca-se a proporção e o cálculo corretos, a boa disposição da página, a feliz escolha de letras, a elegância dos ornamentos, o uso apropriado de sinais, o cuidado com emendas e provas. $\mathrm{E}$ as instruções prosseguem, com considerações sobre capas, folhas de rosto e frontispícios de livros.

É todo um mundo de saberes e técnicas que se descortina, por certo já caídos em desuso, mas nem por isso ausentes do nosso cotidiano. Itálico, sublinhado e negrito, divisão de sílabas, uso de diferentes famílias de letras, espacejamento, colunas, tudo muito familiar para os que lidam com computadores que, de forma automática, respondem aos nossos comandos. Entretanto, basta recuar pouco mais de um século para que tudo passe a depender das mãos hábeis de ciosos compositores tipógrafos.

No momento da publicação do Manual, estava em circulação no Rio de Janeiro a $R e$ vista Tipográfica (1888-1889), que atuava como porta-voz dos que se dedicavam ao ofício. O semanário logo saudou o feito do colega João Henriques, o que permite precisar que a obra veio a público em agosto de 1888 , uma vez que, no dia 18 , nota da redação anunciava:

“O Sr. J. H. de Lima Barreto, habilíssimo e inteligente tipógrafo, um dos chefes de turma da Imprensa Nacional, acaba de traduzir e anotar o Manual do aprendiz compositor, obra tipográfica de subido valor, que deu grande nomeada ao seu autor Mr. Jules Claye. É a primeira obra gráfica que vão possuir as livrarias do Brasil, tornando-se por isso encarecedora e digna de aplausos a feliz lembrança do digno artista, proporcionando-nos conhecimentos muito úteis e aproveitáveis. Se a utilíssima obra [...] é indispensável a todos os cultores das artes gráficas nas grandes capitais, mais precisa e necessária se torna ela nas cidades ínvios sertões das províncias, onde ainda são ignoradas as regras da arte e até os qualificativos porque são conhecidos vários instrumentos usados nas oficinas tipográficas"2.

2 "Manual do aprendiz compositor". Revista Tipogrática, ano 1, n. 24, p. 2, 18/8/1888. Na parte destinada aos anúncios (p. 4), informa-se o custo do exemplar: $2 \$ 000$. A título de comparação, nesse momento a assinatura da publicação na Corte, por três meses, era de $1 \$ 500$. 
O tema da formação do futuro tipógrafo, fosse compositor ou impressor, sempre esteve presente na Revista Tipográfica, tanto que aí se publicaram longas séries sobre a história dos tipos móveis ou acerca das questões técnicas que envolviam não apenas a composição e impressão de textos, mas também a produção e reprodução de imagens, litográficas e xilográficas. Daí a atenção dispensada ao Manual, que a revista se encarregava, inclusive, de comprar e despachar para os leitores residentes fora da capital ${ }^{3}$.

Deve-se saudar a iniciativa de recolocar em circulação o Manual, convite para adentrar e desvendar esse fascinante mundo das oficinas do século XIX, cujo cotidiano pode ser antevisto no "Padre Nosso tipográfico", com sua terminologia específica, decifrável a partir do Manual:

"Chefe nosso que estais na redação, muito boas tardes, que vamos distribuir; venha a nós os vossos originais; seja feita a vossa vontade, assim na composição como na impressão. O salário nosso de cada semana nos dai no sábado. Perdoai-nos, Senhor, os nossos pastéis, assim como nós perdoamos a má letra e as terceiras provas; não nos deixes cair de sono, mas livrai-nos de ficar aqui toda a noite. Amém"4.
3 "O Manual do aprendiz compositor está à venda em algumas livrarias desta corte [...]. Alguns colegas provincianos já nos têm remetido o quantum satis para a compra do mesmo, o que temos feito e enviado pelo correio, sem que para isso exijamos comissão" ("Missivas diversas". Revista Tipográfica, ano I, n. 43, p. 7, 29/12/1888).
4 "Padre Nosso tipográfico". Seção Noticiário. Revista Tipográfica, ano I, n. 26, p. 4, 1\%/9/1888. 